\title{
Who Did Not Read A Sadness in Your Eyes, He Dose Not Deserve Your Heart
}

\author{
Muntaha A Mathkoor* \\ BCABMS (V and D), Ministry of Health, Iraq \\ *Corresponding Author: Muntaha A Mathkoor, BCABMS (V and D), Ministry of \\ Health, Iraq.
}

DOI: $10.31080 /$ ASMI.2020.03.0530
Received: February 07, 2020

Published: February 19, 2020

(C) All rights are reserved by Muntaha A

Mathkoor.
She was hesitating to enter to my room, a young man was with her, while he was pushing the women in front of him, he whispered with words that I could not distinguish. she was pale with dark circle around her eyes, three girls with angelic faces were attached to the end of the woman, s dress with fear in their eyes.

She is bald.. she is bald the man said.

Tears filled her eyes, she bent her head, she looks embarrassing and sad.

But she has the most beautiful eyes I ever seen; I said.

With half smile she expose her hair; The affected area has an irregular angulated border, and the density of hair is greatly reduced; Several short, broken hairs of varying lengths are randomly distributed in the involved site, the diagnosis goes with Trichotillomania (TTM) [1]. The diagnosis was not surprising for me because the Increasing in the prevalence of TTM has been documented in adults with anxiety [1] like my patient, TTM is a behavioural disorder characterized by compulsive hair pulling, It presents as a pattern of hair loss, often bizarre, with no clear biological or overt traumatic explanation [2], there is increased tension immediately before pulling or when attempting to resist the behaviour [2]. Feelings of pleasure, gratification, or relief from pulling out the hair are characteristic, Hair is twisted around the finger and pulled or rubbed until extracted or broken [1]. The favorite site is the easily reached frontoparietal region of the scalp, but any scalp area or the eyebrows and eyelashes may be attacked [1]. TTM is seen more commonly in females than in males, and in children more than adults [3] The average age of onset is 11 to 13 years [1]. If patients are psychologically stable they require only a discussion of the problem with an understanding physician or parent because Many of these cases resolve spontaneously [1]. Advise parents to divert the child's attention when hair is being pulled and to be accepting and supportive rather than judgmental or punitive [1], If patient with TTM psychologically unstable like in this case; the habit should undergo psychiatric evaluation; The establishment of a relationship between the physician and the patient is an important step in the management of TTM [4] so I talked with her to know if she abused physically or emotionally by his husband, she was listen to me with crying eyes; He violent with me even in front of my kids but I can not leave him; I love him; Iove him so much, She said. Here I decided to consult a psychiatric and Marital relationship specialist, may be improve her relationship with his husband but I believe Who did not read a sadness in your eyes, he dose not deserve your heart.

\section{Bibliography}

1. Thomas P Habif Hair Diseases. "Clinical Dermatology Acolor Guide to Diagnosis and Therapy, sixth edition 923-959.

2. Hautmann G., et al. "Trichotillomania". J Am Acad Dermatol 46 (2002): 807-821.

3. Leonard C Sperling., et al. 3rd ed. Saunders-Elsevier; inc10931126.

4. Andrew G., et al. "Acquired Disorders of Hair, Rook's Textbook of Dermatology, Ninth Edition. Edited by Christopher Griffiths, Jonathan Barker, Tanya Bleiker, Robert Chalmers and Daniel Creamer (2016).

\section{Assets from publication with us}

- Prompt Acknowledgement after receiving the article

- Thorough Double blinded peer review

- Rapid Publication

- Issue of Publication Certificate

- High visibility of your Published work

Website: https://www.actascientific.com/ Submit Article: https://www.actascientific.com/submission.php Email us: editor@actascientific.com

Contact us: +919182824667 